\title{
Insight
}

\section{Contracts or Scripts? A Critical Review of the Application of Institutional Theories to the Study of Environmental Change}

\author{
$\underline{\text { Samy Hotimsky }}{ }^{1}$, Richard Cobb $^{1}$, and $\underline{\text { Alan Bond }}^{1}$
}

\begin{abstract}
The impact of new institutionalism on the study of human environment interactions has been meaningful. Institutional perspectives have further shaped and modified the field problems of common pool resources, environmental hazards, and risk and environmental management. Given the relative potential of institutional theories to increase the comprehension of the various dimensions of humanenvironmental interactions, it has become increasingly important to attempt to consolidate different interpretations of what institutions are, and how they mediate and constrain possibilities for more successful environmental outcomes. This article focuses primarily on contending ontological perspectives on institutions and institutional change. It argues that what should guide the application of institutional theories in practical research regarding environmental change is the ontological dimension, and that the focus of research should be on uncovering the underlying dynamics of institutional change. In doing so, it calls for a methodological pluralism in the investigation of the role institutions play in driving/managing for environmental change.
\end{abstract}

Key Words: Adaptation; environmental change; institutions; ontology

\section{INTRODUCTION}

Multiple social science perspectives have produced knowledge on human-environment interactions and on processes of human-induced environmental change. These different analytical frameworks provide a "balance in research and policy on environmental issues" that would not otherwise be achieved (Adger et al. 2005). The institutional perspective, for example, experienced a renaissance in the last decades of the $20^{\text {th }}$ century in a variety of social disciplines (Hall and Taylor 1996). The resurgence of interest in institutions developed, in part, as a reaction to the behavioral movement, which interpreted collective political and economic behavior as the aggregate consequence of individual choice (Powell and DiMaggio 1991). Institutionalism, by contrast, is a theoretical strategy that emphasizes institutional theories and seeks to develop and apply them (Jepperson 1991). Institutional theories weigh institutional effects highly relative to other effects, or isolate institutional-caused features of an analytical object. Institutionalism suggests that social systems vary in the extent to which action is attributable to actors, operating in private capacities, rather than conducted by authorized collective agents of one sort or another (Hall and Taylor 1996). Institutionalism has tended to "defocalize actors" (Jepperson 1991:158).

The interdisciplinary field of environmental social science has been much influenced by the institutional wave of scientific analysis (Berkhout et al. 2003, Paavola and Adger 2005). In the common-pool resource literature, for example, institutional perspectives highlighted the importance of resources and property institutions in mediating environmental outcomes (Bromley 1992, Baland and Platteau 1996, Dietz et al. 2003). Lessons from local and global common-pool resources exemplified the influence of different property rights regimes in providing appropriate incentives for the successful management of fishing grounds, forests, the global atmosphere, groundwater, and other types of resources (Blomquist 1994, Ostrom et al. 1999, Dolsak and Ostrom 2003). In the hazards and development fields, institutional perspectives shed light on the types of social and economic interactions that drive patterns of human vulnerability to environmental uncertainty and risk 
(Bohle et al. 1994, Scoones et al. 1996, Ribot et al. 1996). The perception that social institutions play a fundamental role in defining the "social space of vulnerability" (Watts and Bohle 1993:54), contributed to the establishment of a human ecology perspective on studies related to environmental hazards (Hewitt 1997). Institutionalism also promoted the necessary theoretical framework for the conceptualization of livelihood security and diversity in studies of economic and social development of poorer households (Ellis 2000, Haan and Zoomers 2005).

Given the relative potential of institutional theories to increase our comprehension over the various dimensions of human-environmental interactions, it has become increasingly important to attempt to consolidate different interpretations of what institutions are, and how they influence social and environmental outcomes. O'Riordan and Jordan (1999) made such an attempt when reviewing the status of new institutionalism and its importance in the interpretation and resolution of climate change. Johnson (2004) also described the application of institutional theories by scholars of environmental conservation and conflict. His focus was on differing epistemological and methodological approaches by those who favor what he calls a sociological-historical approach and a "mainstream common property approach" based on positivist social science and methodological individualism. This article focuses primarily on contending ontological perspectives on institutions and institutional change. It argues that what should guide the application of institutional theories in practical research regarding environmental change is the ontological dimension, and that the focus of research should be on uncovering the underlying dynamics of institutional change. In doing so, it calls for a methodological pluralism in the investigation of the role institutions play in driving or managing for environmental change. First, we present the differing ontological perspectives on institutional change. Then, we discuss how the institutional perspective may be better applied for the study of environmental change. Finally, we suggest future research directions.

\section{ONTOLOGICAL PERSPECTIVES ON INSTITUTIONAL CHANGE}

In sociology, the core denotation of institution is "an organized, established, procedure" (Jepperson
1991:143). In this context, an institution represents a social order or pattern (i.e., standardized interaction sequences) that has attained a certain state or property. Institutionalization denotes the process of such attainment. In economics, institutions are interpreted as formal rules (e.g., judicial, political, economic rules and contracts) and informal constraints (North 1990). In the economic sense, institutions provide structure for exchange, lowering uncertainties and establishing transaction and transformation costs. They help determine the opportunities in a society by established "rules of the game" (Ostrom et al. 1994, Goodin 2000). Sociology offers a broader interpretation of institutions, as variously "production systems, enabling structures, social programs or performance scripts" (Jepperson 1991:145). In the sociological sense, institutions are not just constraints, but they simultaneously empower and control social agents (Sewell 1992). Social structures are reproduced by agents considered knowledgeable in everyday life and the reciprocal reference of their actions to shared typifications in society (Reich 2000). In this way, institutions become the "more enduring features of social life" (Giddens 1984:24).

The new institutionalism in economics stresses the role of strategic interaction in the determination of social outcomes by focusing largely on property rights, rent-seeking, and transaction costs (Hall and Taylor 1996). The theory postulates that an actor's behavior is likely to be driven, not by impersonal historical forces, but by a strategic calculus and, second, that this calculus will be deeply affected by the actor's expectations about how others are likely to behave as well. Institutions structure interactions by either affecting the range of available alternatives or by providing information and enforcement processes that reduce uncertainty about the corresponding behavior of others, thus allowing gains from exchange (Ostrom et al. 1999, Goodin 2000). Institutional arrangements are viewed as "adaptive solutions to problems of opportunism, imperfect or asymmetric information and costly monitoring" (Powell and DiMaggio 1991:9).

For new institutional economics, institutions arise and persist when they confer benefits greater than the transaction costs incurred in creating and sustaining them (North 1990, Ostrom 1990). Previously existing institutions, that is, formal laws and regulations, informal laws and ideologies, constrain the range of institutional alternatives. In this way, the extent to which new institutions differ 
from old ones is limited, mitigating against more radical and abrupt institutional change (North 1990). A similar reasoning to the causes of institutional change is offered by political scientists attesting to functionalist arguments (Pierson 2000). The basic functionalist assumption is that institutions exist in the form they do because they are functional for social actors, in particular, for their role in solving collective action problems and allowing actors to "achieve joint gains through cooperation and exchange" (Thelen 2003:214). Institutional genesis is explained by the efforts of rational choice actors to design appropriate institutions to fulfill certain functions, as an act of "crafting institutions" (Ostrom 1992). This could result either in incremental or abrupt change (i.e., institutional transformation) as a shift in environmental or other conditions render the existing institutions dysfunctional (Thelen 2003). Institutional reproduction is explained specifically because of its functional consequences (i.e., integration, adaptation, survival) for a larger system within which the institution is embedded.

Institutional sociology adds to the explanation of institutional persistence (stickiness) and change arguments in favor of shared cultural understandings, and the importance of power and legitimacy in understanding processes that hamper and promote change (Thelen 1999). Social constructionist views hold that actors suffer from limited information and high levels of uncertainty and thus are more driven by concerns for doing what is institutionally acceptable and culturally appropriate than by some kind of cost-benefit analysis (Powell and DiMaggio 1991). The market, is seen not only as an allocative mechanism but also "an institutionally specific cultural system for generating and measuring value" (Friedland and Alford 1991:234). Social actors construct new institutions by extending already existing institutional principles, conventions, and concepts to new realms of activity. In this way, institutions provide actors with social scripts that enable them in ways that contribute to the evolutionary nature of institutional change (Jepperson1991).

Social constructionists argue that individuals can manipulate or reinterpret symbols and practices, and thus, are "artful in the mobilization of different institutional logics to serve their purposes" (Friedland and Alford 1991:254). Sometimes rules and symbols are internalized and result in almost universal conformity, but sometimes they are resources manipulated by individuals, groups, and organizations. Moreover, the success of an attempt at institutional change depends not only on the resources controlled by its proponents, but on the nature of power and the institutionally specific rules by which resources are allocated, produced, and controlled. In the words of Friedland and Alford (1991:254), "the institutional nature of power provides specific opportunities for not only reproduction, but transformation as well." By stressing the role of power in explaining institutional change, social institutionalists emphasise "isomorphism instead of coordination effects" as the main mechanism of institutional reproduction (Thelen 1999:387).

Like utilitarian analysts, power explanations of selfreinforcing processes may also assume that actors make decisions by weighing costs and benefits, but that institutions distribute these costs and benefits unevenly. In a power-centered approach, an institution can persist even when most individuals or groups prefer to change it, given that an elite that benefits from the existing arrangement has sufficient strength to promote its reproduction (Thelen 2003). In this way, self-reinforcing processes are explained by an outgrowth of preexisting power arrangements where institutions gradually increase the power of the advantaged group to the detriment of other groups (Mahoney 2000). Institutional transformation becomes possible when the inherent conflict between the different societal groups reaches a critical threshold point, where subordinate groups successfully challenge the prevailing arrangements.

Different from power arguments, legitimation is grounded in actors' subjective orientations and beliefs about what is considered appropriate or morally correct (Thelen 2003). Institutional reproduction occurs because, as actors view institutions as being appropriate or legitimate, this forms a basis for making future decisions about what is appropriate by a positive feedback process of increasing legitimation. Beliefs in the legitimacy of an institution may range from "active moral approval to passive acquiescence in the face of the status quo" (Mahoney 2000:523). Institutional transformation may come about by arising inconsistencies between multiple cognitive frameworks that are predominant in society, providing a basis for actors to adopt new subjective evaluations and moral codes concerning appropriateness. 
The utilitarian/functionalist, power-distribution, and legitimacy accounts specify various processes of genesis and reproduction that may be sustaining different institutional arrangements through time (Table 1). Institutional theories (i.e., historical institutionalism) also recognize the importance of path dependency and contingency in determining social outcomes (Steinmo et al. 1992, Hall and Taylor 1996, Greif 1998). Contemporary arguments on path dependence emphasize moments of institutional innovation in which agency, choice, and contingency figure prominently. Such moments are then followed by institutional reproduction where the importance of strategy and choice recede relative to processes of adaptations to institutional incentives and constraints (Thelen 2003). Contingency referes to "the inability of theory to predict or explain, either deterministically or probabilistically, the occurrence of a specific outcome" (Mahoney 2000:513).

This treatment of institutional change largely attests to the notion that the factors responsible for the genesis of an institution may not be the same as those that sustain it over time (Stinchcombe 1968). In other words, much of the analysis tends to encourage a strict separation of the issues of institutional innovation and institutional reproduction. Such a perspective sees institutions as the products of specific historical episodes (e.g., critical junctures and breakpoints) that result in configurations that then set constraints on subsequent development. Formal institutions will often "neither accurately reflect the congealed tastes of their creators, nor simply mirror the present prevailing power distribution" (Thelen 2003:230; italics given by the author). These conceptualizations of institutional change offer an opportunity for a more nuanced analysis of when and how particular aspects may be more amenable to change than others. It also draws attention to the ways in which adaptation to other ongoing processes (and not just the positive feedbacks generated by the process itself) contributes to institutional continuities over long periods of time. Thus, institutions evolve in ways that-even if not predictable ex antenonetheless, follow a particular logic that makes sense only against the backdrop of the institutional context in which the next steps are constantly being renegotiated under the notion of "bounded change" (Weir 1992).

\section{INSTITUTIONS IN THE CONTEXT OF ENVIRONMENTAL CHANGE}

The utilitarian/functionalist accounts rely mainly on efficiency arguments regarding the institutional role of facilitating actors to achieve joint gains through cooperation and exchange. The primary features of institutions as systems of rules and procedures articulated in contracts, constitutions, and treaties (i.e., constitutive documents), drive the decisionmaking process. Academics will seek to design arrangements that alter the structure of (dis) incentives that actors face in order to produce successful environmental outcomes: a process termed "crafting" (see Ostrom 1992, Ostrom et al. 1994). In this way, a rational manipulation of preexisting institutional arrangements by social actors becomes a real possibility (Rudd 2004). Instrumental action, governed by pre-existing technical rules, takes the forefront in pursuit of more effective institutional arrangements. This "logic of consequences" assumes that actors respond accordingly to changes in costs and benefits associated with available options that serve a functional purpose (Young 2002). This approach is firmly rooted in an epistemology that seeks to build predictive theories about the robustness of common property regimes based on a hypothetico-deductive search for falsifiable claims about processes of environmental change.

In contrast, power-distribution/legitimacy accounts stress the importance of de facto (rules-in-use) arrangements for governing decisions rather than $d e$ jure (rules-on-paper) arrangements sometimes defined as "dead letters" (Young 2002:6). This "logic of appropriateness" assumes that actors behave in ways that they deem as right or proper, and that they will normally accept restrictions that they perceive to be legitimate. Behavior is generally "guided by underlying principles interpreted as fair or just" (Young 2002:18). Academics who favor this logic contextualize environmental challenges in historical, political, cultural, and biogeographical frames (McCay 2002). This requires a greater attention to the "embeddedness of individual and social action, and the historical, political, sociocultural, and ecological specificity of humanenvironment interactions and institutions" (McCay 2002:362). Patterns of environmental change are translated into outcomes of negotiation, or contestation, between social actors with different interests and legitimizing systems of social norms and customary rights. Institutions, in this sense, co- 
Table 1. Typology of possible explanations for institutional change

\begin{tabular}{|c|c|c|c|c|}
\hline & Utilitarian explanation & Functional explanation & Power explanation & Legitimation explanation \\
\hline $\begin{array}{l}\text { Mechanism of } \\
\text { genesis }\end{array}$ & $\begin{array}{l}\text { Institution is established to } \\
\text { minimize transaction costs }\end{array}$ & $\begin{array}{l}\text { Institution is crafted in } \\
\text { order to overcome } \\
\text { collective action } \\
\text { problems }\end{array}$ & $\begin{array}{l}\text { Institution is } \\
\text { established out of } \\
\text { political conflict and } \\
\text { strategic bargaining }\end{array}$ & $\begin{array}{l}\text { Institution is } \\
\text { constructed based on a } \\
\text { social definition of } \\
\text { reality }\end{array}$ \\
\hline $\begin{array}{l}\text { Mechanism of } \\
\text { reproduction }\end{array}$ & $\begin{array}{l}\text { Institution is reproduced } \\
\text { through the rational cost- } \\
\text { benefit assessments of } \\
\text { actors }\end{array}$ & $\begin{array}{l}\text { Institution is reproduced } \\
\text { because it serves a } \\
\text { function for an overall } \\
\text { system }\end{array}$ & $\begin{array}{l}\text { Institution is } \\
\text { reproduced because it } \\
\text { is supported by an } \\
\text { elite group of actors }\end{array}$ & $\begin{array}{l}\text { Institution is } \\
\text { reproduced because } \\
\text { actors believe it is } \\
\text { morally just or } \\
\text { appropriate }\end{array}$ \\
\hline $\begin{array}{l}\text { Mechanism of } \\
\text { transformation }\end{array}$ & $\begin{array}{l}\text { Increased competitive } \\
\text { pressures; learning } \\
\text { processes }\end{array}$ & $\begin{array}{l}\text { Exogenous shock that } \\
\text { transforms system needs }\end{array}$ & $\begin{array}{l}\text { Weakening of elites } \\
\text { and strengthening of } \\
\text { subordinate groups }\end{array}$ & $\begin{array}{l}\text { Changes in the values } \\
\text { or subjective beliefs } \\
\text { of actors }\end{array}$ \\
\hline
\end{tabular}

Adapted from Mahoney (2000).

evolve by incorporating rituals and informal ecological knowledge encoded in cultural practices of daily life (Berkes and Farvar 1989, Norgaard 1994, Berkes and Folke 1998).

Johnson (2004:428) describes these two contending epistemological applications as tensions that exist because of a "divergence between a social science which seeks to build theory on the basis of scientific empiricism and an ethnography which rejects the universalism that underlies the scientific approach." The author continues to assert that "the problem this creates for the study of social phenomena (such as common property relations) is that proponents of context and ethnographic method and those favouring a scientific frame are left with little common ground to stand on." we argue that what could break this impasse is a switch from epistemology to ontology as a point of departure in the investigation of institutions and environmental change. Ontological considerations on what properties and dimensions social institutions possess should guide methodology and practical research. Moreover, institutions as either predominantly based on incentive structures or cultural/behavioral and distributive frames should not be regarded as exclusive, but complementary views in the investigation of environmental change.

Rights and relationships governing who has access and control over resources tend to change over time. These are driven by both rights-based considerations and specific political-economic and cultural frames within which access to resources is sought (Ribot and Peluso 2003). Conflicts over the management of common-pool resources depend not only on material interests, but also on belief systems, power relations, and common frames of reference. Adams et al. (2005:1915) assert that policy debates over common-pool dilemmas tend to "ignore the fact that the assumptions, knowledge, and understandings that underlie the definition of resource problems are frequently uncertain and contested." In Zimbabwe, for example, the embedded nature of bureaucratic attitudes and practices, shaped by science, provided the basis for the persistence of a technocratic style 
of state response to environmental and land management issues (Keeley and Scoones 2003). Collective environmental decisions often reflect a balance between socially acknowledged and supported claims or rights, and ideological and discursive manipulations, as well as relations of production and exchange, that differentiate access properties to environmental resources. Downing and Baker (2000) found evidence in rural Botswana that official discourses proclaiming the severity of drought events legitimized the processes that were increasing dependency of more vulnerable groups on rural elites, who saw an opportunity for the consolidation of wealth with the commoditization of agriculture and privatization of production. In Indonesia, the effectiveness of local forest conservation units was severely hampered by policy narratives that prioritized aquaculture intensification to the detriment of mangrove conservation, reflecting the interests of more powerful social groups (Armitage 2002). Paavola and Adger (2005:365) mention that the institutional approach "suggests that more attention ought to be given to processes and procedures in environmental decision making in order to guarantee adequate learning and fair representation of affected parties and legitimacy of environmental decisions." Broader interpretations of what institutions are, and their role in driving social-ecological outcomes would, at least, shed light on environmental governance goals held by a wider audience of decision makers and stakeholders.

Another key development for the use of institutional theories to investigate environmental change would be a switch from an ontology based on "static" institutions to generative processes of institutional change as primary objects of study. This would facilitate the task of uncovering causal relationships between social institutions and environmental outcomes (Stern et al. 2002). Social institutions rest on multiple foundations (i.e., belief systems, power arrangements, functional properties, etc.), and thus the process of institutional dynamics may be best described as interplay between these different foundations. Different processes of institutional change, such as those delineated in Table 1, may either be self-reinforcing or transformative, or they may cause institutional breakdown at a given moment in time. Legitimizing accounts, for example, can influence the effectiveness of utilitarian and functional processes, and even make them unsuitable for governing resource use. The padu system of community-based fisheries management in South India arose out of local contestations of the state-sanctioned property rights regime for shrimp exploitation (Lobe and Berkes 2004). Local groups organized themselves in order to present their collective claim to a stake of the net fishery based on their traditional caste-based right, instead of obeying the licensing arrangements promoted by the centralized government. Distributional effects of newly established institutional arrangements may also hamper the success of utilitarian-based environmental regimes. In Vietnam, for example, increased social inequality in resource-dependent coastal communities, caused by the ascendancy of private property ownership in mangrove areas, led to a breakdown in collective action arrangements previously established to manage such resources (Adger 2000).

The research problem becomes one of investigating how (when and by whom) the partial renegotiation and redirection of (which) elements of a given set of institutions take place to minimize environmental deterioration and social vulnerability. Of particular interest are transformative processes that modify pre-existing structures of environmental governance in order to minimize situations of risk-the risk of losing access to those resources that safeguard livelihood security and human well-being. Berkes et al. (2003:11) assert that "adaptive capacity of all levels of society is constrained by the resilience of their institutions and the natural systems on which they depend. The greater their resilience, the greater is their ability to absorb shocks and perturbations and adapt to change. Conversely, the less resilient the system, the greater is the vulnerability of institutions and societies to cope and adapt to change." In fact, Adger (2003:33) argues that "adaptive capacity is only potential until there are governance institutions that make it realizable." A more directed research focus toward transformative processes could aid the understanding of how creative opportunities for institutional adaptation emerge in order to better address environmental challenges facing sensitive geographical regions (see, e.g., Olsson et al. (2004)).

It is essential that the research problem just described be grounded on the basis of metatheoretical considerations regarding institutional change, by the application of an appropriate ontological-methodological link. The decisive question should be how different methodologies can be best applied in order to convey knowledge about the generative processes of institutional change. 
Complementary empirical procedures should be viewed as being part of a greater whole, namely the research process guided by a critical ontology. This methodological pluralism should allow for the investigation of acting people and social institutions in the context of environmental change as two separate entities - both with properties and powers of their own. As Dietz et al. (2003:1907) claim: "People bring varying perspectives, interests, and fundamental philosophies to problems of environmental governance, and their conflicts, if they do not escalate to the point of dysfunction, can spark learning and change."

\section{CONCLUSIONS}

The application of institutional perspectives to the study of human-environmental interactions will undoubtedly grow in importance in the future (see Adger et al. 2005). In order to channel research efforts into more productive venues, we would argue that, first, differing ontological perspectives of what institutions are should not be discarded when research questions are framed. Second, a nuanced analysis of the interplay between different processes of institutional innovation, reproduction, and transformation is critical for a better understanding of institutional forces as drivers of environmental change. Of particular interest, are the transformative aspects of institutions already set to govern resource access and use. Finally, we would argue that, due to increasing rates of environmental change (Folke et al. 2002) caused by climate change (McCarthy et al. 2001) and other factors (Dietz et al. 2003), the goal of institutional research applied to human-environmental interactions should be to advance our knowledge about how generative processes of institutional change shape and modify social institutions to safeguard a sound level of reflexivity and flexibility. In this way, institutional resilience may be enhanced and society may become better able to generate novel solutions or policies for chronic resource issues.

Responses to this article can be read online at: http://www.ecologyandsociety.org/voll1/iss 1/art41/responses/

\section{LITERATURE CITED}

Adams, W. M., D. Brockington, J. Dyson, and B. Vira. 2005. Managing tragedies: understanding conflict over common pool resources. Science 302:1915-1916.

Adger, W. N. 2000. Institutional adaptation to environmental risk under the transition in Vietnam. Annals of the Association of American Geographers 90(4):738-758.

Adger, W. N. 2003. Social aspects of adaptive capacity. Pages 29-49 in J. B. Smith, R. T. Klein, and $\mathrm{S}$. Huq, editors. Climate change, adaptive capacity and development. Imperial College Press, London, UK.

Adger, W. N., K. Brown, and M. Hulme. 2005. Redefining global environmental change. Global Environmental Change 15:1-4.

Armitage, D. 2002. Socio-institutional dynamics and the political ecology of mangrove forest conservation in Central Sulawesi, Indonesia. Global Environmental Change 12: 203-217.

Baland, J.-M., and J.-P. Platteau. 1996. Halting degradation of natural resources: is there a role for rural communities? Clarendon Press, Oxford, UK.

Berkes, F., and M. T. Farvar, editors. 1989. Common property resources: ecology and community-based sustainable development. Belhaven Press, London, UK.

Berkes, F., and C. Folke. 1998. Linking social and ecological systems for resilience and sustainability. Pages 1-25 in F. Berkes and C. Folke, editors. Linking social and ecological systems: management practices and social processes for building resilience. Cambridge University Press, Cambridge, UK.

Berkes, F., J. Colding, and C. Folke, editors. 2003. Navigating social-ecological systems. Cambridge University Press, Cambridge, UK.

Berkhout, F., M. Leach, and I. Scoones. 2003. Shifting perspectives in environmental social sciences. Pages 1-31 in F. Berkhout, M. Leach, and I. Scoones, editors. Negotiating environmental change: new perspectives from social science. Edward Elgar Publishing, Cheltenham, UK. 
Blomquist, W. 1994. Changing rules, changing games: evidence from groundwater systems in southern California. Pages 283-300 in E. Ostrom, R. Gardner, and J. Walker, editors. Rules, games and common-pool resources. The University of Michigan Press, Ann Arbor, Michigan, USA.

Bohle, H. G., T. E. Downing, and M. J. Watts. 1994. Climate change and social vulnerabilitytowards a sociology and geography of food insecurity. Global Environmental Change 4:37-48.

Bromley, D. W., editor. 1992. Making the commons work: theory, practice and policy. ICS Press, San Fransisco, California, USA.

Dietz, T., E. Ostrom, and P. Stern. 2003. The struggle to govern the commons. Science 302:19071912 .

Dolsak, N., and E. Ostrom. 2003. The challenges of the commons. Pages 3-34 in N. Dolsak, and E. Ostrom, editors. The commons in the new millennium-challenges and adaptations. MIT Press, Cambridge, Massachussetts, USA.

Downing, T. E., and K. Baker. 2000. Drought discourse and vulnerability. Pages 213-230 in D. A. Wilhite, editor. Drought: a global assessment. Routledge, London, UK.

Ellis, F. 2000. Rural livelihoods and diversity in developing countries. Oxford University Press, Oxford, UK.

Folke, C., S. Carpenter, T. Elmqvist, L. Gunderson, C. S. Holling, and B. Walker. 2002. Resilience and sustainable development: building adaptive capacity in a world of transformations. Ambio 31:437-440.

Friedland, R., and R. R. Alford. 1991. Bringing society back in: symbols, practices and institutional contradictions. Pages 232-263 in W. W. Powell and P. J. DiMaggio, editors. The new institutionalism in organizational analysis. The University of Chicago Press, Chicago, Illinois, USA.

Giddens, A. 1984. The constitution of society: outline of the theory of structuration. Polity Press, Cambridge, UK.

Goodin, R. E. 2000. Institutional gaming. Governance 13(4):523-533.
Grief, A. 1998. Historical and comparative institutional analysis. American Economic Review 88(2):80-84.

Haan, L., and A. Zoomers. 2005. Exploring the frontier of livelihoods research. Development and Change 36:27-47.

Hall, P. A., and R. C. R. Taylor. 1996. Political science and the three new institutionalisms. Political Studies XLIV:936-957.

Hewitt, K. 1997. Regions of risk: a geographical introduction to disasters. Longman, Harlow, UK.

Jepperson, R. L. 1991. Institutions, institutional effects, and institutionalism. Pages 143-163 in W. W. Powell, and P. J. DiMaggio, editors. The new institutionalism in organizational analysis. The University of Chicago Press, Chicago, Illinois, USA.

Johnson, C. 2004. Uncommon ground: the "poverty of history" in common property discourse. Development and Change 35:407-433.

Keeley, J., and I. Scoones. 2003. Understanding environmental policy processes: cases from Africa. Earthscan, London, UK.

Lobe, K., and F. Berkes. 2004. The padu system of community-based fisheries management: change and local institutional innovation in south India. Marine Policy 28:271-281.

Mahoney, J. 2000. Path dependence in historical sociology. Theory and Society 29:507-548.

McCarthy, J. J., O. Canziani, N. A. Leary, D. J. Dokken, and K. S. White, editors. 2001. Climate change 2001: impacts, adaptation and vulnerability. IPCC Working Group II. Cambridge University Press, Cambridge, UK.

McCay, B. J. 2002. Emergence of institutions for the commons: contexts, situations, and events. Pages 361-402 in E. Ostrom, T. Dietz, N. Dolsak, P. C. Stern, S. Stonich, and E. U. Weber, editors. The drama of the commons. National Academy Press, Washington, D.C., USA.

Norgaard, R. B. 1994. Development betrayed: the end of progress and a coevolutionary revisioning of the future. Routledge, London, UK. 
North, D. C. 1990. Institutions, institutional change and economic performance. Cambridge University Press, Cambridge, UK.

Olsson, P., C. Folke, and T. Hahn. 2004. Socialecological transformation for ecosystem management: the development of adaptive co-management of a wetland landscape in southern Sweden. Ecology and Society 9(4):2. [online] URL: http://www.ecolo gyandsociety.org/vol9/iss4/art2/.

O'Riordan, T., and A. Jordan. 1999. Institutions, climate change and cultural theory: towards a common analytical framework. Global Environmental Change 9:81-93.

Ostrom, E. 1990. Governing the commons: the evolution of institutions for collective action. Cambridge University Press, Cambridge, UK.

Ostrom, E. 1992. Crafting institutions for selfgoverning irrigation systems. Institute for Contemporary Studies Press, San Francisco, California, USA.

Ostrom, E., R. Gardner, and J. Walker. 1994. Rules, games and common-pool resources. The University of Michigan Press, Ann Arbor, Michigan, USA.

Ostrom, E., J. Burger, and C. B. Field. 1999. Revisiting the commons: local lessons, global challenges. Science 284:278-282.

Paavola, J., and W. N. Adger. 2005. Institutional ecological economics. Ecological Economics 53:353-368.

Pierson, P. 2000. Increasing returns, path dependence, and the study of politics. The American Political Science Review 94:251-267.

Powell, W. W., and P. J. DiMaggio, editors. 1991. The new institutionalism in organizational analysis. The University of Chicago Press, Chicago, Illinois, USA.

Reich, S. 2000. The four faces of institutionalism: public policy and pluralistic perspective. Governance 13:501-522.

Ribot, J. C., A. R. Magalhães, and S. S. Panagides. 1996. Climate variability, climate change and social vunerability in the semi-arid tropics. Cambridge University Press, Cambridge, UK.

Ribot, J. C., and N. L. Peluso. 2003. A theory of access. Rural Sociology 68:153-181.

Rudd, M. A. 2004. An institutional framework for designing and monitoring ecosystem-based fisheries management policy experiments. Ecological Economics 48:109-124.

Sage, C. 2002. Food security. Pages 128-153 in E. A. Page and M. Redclift, editors. Human security and the environment: international comparisons. Edward Elgar, Cheltenham, UK.

Scoones, I. C., C. Chibudu, S. Chikura, S., and P. Jeranyama. 1996. Hazards and opportunities: farming livelihoods in dryland Africa: lessons from Zimbabwe. Zed Books, London, UK.

Sewell, W. H. 1992. A theory of structure: duality, agency, and transformation. American Journal of Sociology 98(1):1-29.

Steinmo, S., K. Thelen, and F. Longstreth, editors. 1992. Structuring politics: historical institutionalism in comparative analysis. Cambridge University Press, Cambridge, UK.

Stern, P. C., T. Dietz, N. Dolsak, E. Ostrom, and S. Stonich. 2002. Knowledge and questions after 15 years of research. Pages 445-479 in E. Ostrom, T. Dietz, N. Dolsak, P. C. Stern, S. Stonich, and E. $\mathrm{U}$. Weber, editors. The drama of the commons. National Academy Press, Washington, D.C., USA.

Stinchcombe, A. L. 1968. Constructing social theories. Harcourt, Brace \% World, New York, New York, USA.

Thelen, K. 1999. Historical institutionalism in comparative politics. Annual Review of Political Science 2:369-404.

Thelen, K. 2003. How institutions evolve. Pages 208-240 in J. Mahoney and D. Rueschemeyer, editors. Comparative historical analysis in the social sciences. Cambridge University Press, Cambridge, UK.

Watts, M. J., and H. G. Bohle. 1993. The space of vulnerability: the causal structure of hunger and famine. Progress in Human Geography 17(1):43- 
67.

Weir, M. 1992. Ideas and the politics of bounded innovation. Pages 188-216 in S. Steinmo, K. Thelen, and F. Longstreth, editors. Structuring politics: historical institutionalism in comparative analysis. Cambridge University Press, Cambridge, UK.

Young, O. 2002. The institutional dimensions of environmental change: fit, interplay, and scale. MIT Press, Cambridge, Massachusetts, USA. 